\title{
TELAAH KRITIS TERHADAP PERENCANAAN DALAM PROSES PEMBELAJARAN
}

\author{
M. Yusuf Seknun \\ Fakultas Tarbiyah dan Keguruan UIN Alauddin Makassar \\ Kampus II: Jalan Sultan Alauddin Nomor 36 Samata-Gowa \\ Email: muh.yusufseknun@yahoo.com
}

\begin{abstract}
Abstrak:
Tulisan ini mengkaji secara kritis mengenai perencanaan dalam proses pembelajaran. Tujuan dari tulisan ini adalah membangun pemahaman yang jelas dan utuh tentang mengapa dan bagaimana merancang suatu bentuk pembelajaran yang sistematis, terencana, terarah, dan efektif. Keberhasilan pendidikan banyak ditentukan bagaimana optimalisasi upaya pendidik dalam merencanakan dan melaksanakan serta mengevaluasi sistem pembelajarannya. Perencanaan dalam proses pembelajaran merupakan skenario pembelajaran yang menjadi acuan pelaksanaan program pembelajaran bagi pihak pendidik, dan pengalaman belajar yang sistematis dan efektif bagi pihak peserta didik. Penyusunan perencanaan program pembelajaran sebagai suatu proses melibatkan berbagai aspek seperti kedisiplinan, ilmu pengetahuan, realitas, sistem dan teknologi pembelajaran sehingga pelaksanaan pembelajaran berjalan lebih lancar dan hasilnya lebih baik.
\end{abstract}

\begin{abstract}
:
This article discusses about planning in an instructional process. The purpose of the writing is to deepen a clear and whole understanding of how and why the instruction should be designed in the systematic, planned, oriented, and effective forms. The successfulness of education is mostly influenced by how the teachers' role optimalized in designing, implementing, and evaluating the instructional system. Instructional design is an instructional scenario that becomes a reference for implementing of the instructional program done by educators and a systematic and effective learning experience for learners. The arrangement of instructional program as a process involves many aspects such as discipline, knowledge, reality, system, and technology of instruction so that the implementation of instruction can run well and get a very good result.
\end{abstract}

Kata kunci:

Perencanaan, pembelajaran, perencanaan pembelajaran

SECARA mendasar, pendidikan adalah segala situasi hidup yang mempengaruhi pertumbuhan individu sebagai pengalaman belajar yang berlangsung dalam segala lingkungan dan sepanjang hidup. Dalam arti sempit pendidikan adalah pembelajaran yang diselenggarakan umumnya di sekolah sebagai lembaga pendidikan formal. Sedangkan para ahli psikologi memandang pendidikan sebagai pengaruh orang dewasa terhadap anak yang belum dewasa agar mempunyai kemampuan yang sempurna dan kesadaran penuh terhadap hubungan-hubungan dan tugas-tugas sosialnya dalam masyarakat.

Dilihat dari sudut proses bahwa pendidikan adalah proses dalam rangka memengaruhi peserta didik supaya mampu menyesuaikan diri sebaik mungkin 
dengan lingkungannya dan yang akan menimbulkan perubahan pada dirinya yang memungkinkan berfungsi sesuai kompetensinya dalam kehidupan masyarakat. ${ }^{1}$

Dengan demikian, pendidikan adalah usaha sadar yang dilakukan oleh keluarga, masyarakat dan pemerintah melalui bimbingan, pembelajaran dan atau latihan yang berlangsung di sekolah dan luar sekolah. Usaha sadar tersebut dilakukan dalam bentuk pembelajaran di mana ada pendidik yang melayani para peserta didik dalam melakukan kegiatan belajar dan pendidik menilai atau mengukur tingkat keberhasilan belajar peserta didik tersebut dengan prosedur yang ditentukan.

Menurut Charles E. Silberman dalam Abuddin Nata, pendidikan tidak sama dengan pembelajaran, karena pembelajaran hanya menitikberatkan pada usaha mengembangkan intelektualitas manusia. Sedangkan pendidikan berusaha mengembangkan seluruh aspek kepribadian dan kemampuan manusia, baik dilihat dari aspek kognitif, afektif dan psikomotorik. Pendidikan mempunyai makna yang lebih luas dari pembelajaran, tetapi pembelajaran merupakan sarana yang ampuh dalam menyelenggarakan pendidikan. ${ }^{2}$

Jadi, pembelajaran merupakan bagian dari pendidikan, mengacu pada konsep yang lebih luas dan lintas kultural masyarakat Indonesia yang demikian majemuknya, maka pendidikan diselenggarakan berdasarkan rencana yang matang, mantap, jelas dan lengkap, menyeluruh, rasional, dan obyektif menjadikan peserta didik menjadi warga negara yang baik. Keberhasilan pendidikan banyak ditentukan bagaimana optimalisasi upaya pendidik dalam merencanakan dan melaksanakan serta mengevaluasi sistem pembelajarannya.

Namun, tidak dapat dipungkiri bahwa banyak kalangan masyarakat yang mengeritik sistem pembelajaran sekarang ini. Dalam analisis N.S. Degeng, asumsiasumsi yang melandasi program-program pendidikan seringkali tidak sejalan dengan hakikat belajar, hakikat orang yang belajar dan hakikat orang yang mengajar. Dunia pendidikan, lebih khusus lagi dunia belajar, didekati dengan paradigma yang tidak mampu menggambarkan hakikat belajar dan pembelajaran secara komprehensif. Praktik pendidikan dan pembelajaran sangat diwarnai oleh landasan teoretik dan konseptual yang tidak akurat. Pendidikan dan pembelajaran selama ini hanya mengagungkan pada pembentukan perilaku keseragaman, dengan harapan akan menghasilkan keteraturan, ketaatan dan kepastian. ${ }^{3}$

Tantangan dunia pendidikan ke depan adalah mewujudkan proses demokratisasi belajar. Suatu proses pendemokratisasi yang mencerminkan bahwa belajar adalah atas prakarsa anak. Demokrasi belajar berisi pengakuan hak anak untuk melakukan tindakan belajar sesuai dengan karakteristiknya. Salah satu prasyarat terwujudnya masyarakat belajar yang demokratis adalah pengemasan pembelajaran yang beragam dengan cara menghapuskan penyeragaman kurikulum, strategi pembalajaran, bahan ajar, dan evaluasi belajar. ${ }^{4}$

Sering dikatakan mengajar adalah mengorganisasikan aktivitas peserta didik dalam arti yang luas. Peranan guru bukan semata-mata memberikan informasi, melainkan juga mengarahkan dan memberi fasilitas belajar (directing and facilitating 
the learning) agar proses belajar lebih memadai. Dalam pembelajaran guru harus memahami hakikat materi pelajaran yang diajarkannya sebagai suatu pelajaran yang dapat mengembangkan kemampuan berpikir peserta didik, dan memahami berbagai model pembelajaran yang dapat merangsang kemampuan peserta didik untuk belajar dengan perencanaan pembelajaran yang matang oleh guru. ${ }^{5}$

Pendapat ini sejalan dengan Jerome Bruner yang mengatakan bahwa perlu adanya teori pembelajaran yang akan menjelaskan asas-asas untuk merancang pembelajaran yang efektif di kelas. Menurut pandangan Bruner teori belajar itu bersifat deskriptif, sedangkan teori pembelajaran itu preskriptif. ${ }^{6}$ Dengan demikian, setiap pendidik perlu memahami bahwa pembelajaran bukan sekadar men'ceramah'kan bahan ajar di depan kelas atau men'jejal'kan pengetahuan kepada peserta didik tanpa perencanaan yang jelas.

Selanjutnya Syaiful Sagala menyebutkan bahwa pembelajaran mempunyai dua karakteristik, yaitu; Pertama, proses pembelajaran melibatkan proses mental peserta didik secara maksimal, bukan hanya menuntut peserta didik sekadar mendengar, mencatat, tetapi menghendaki aktivitas peserta didik dalam proses berpikir. Kedua, dalam proses pembelajaran dibangun suasana dialogis dan proses tanya jawab terusmenerus yang diarahkan untuk memperbaiki dan meningkatkan kemampuan berpikir peserta didik, yang pada gilirannya kemampuan berpikir itu dapat membantunya untuk memperoleh pengetahuan yang mereka konstruksi sendiri. ${ }^{7}$

Tulisan ini mencoba mengulas tentang telaah kritis tentang perencanaan dan proses pembelajaran. Diharapkan dari ini adanya pemahaman yang jelas dan utuh tentang mengapa dan bagaimana merancang suatu bentuk pembelajaran yang sistematis, terencana, terarah dan efektif. Selain itu, diharapkan dari setiap pendidik/ guru agar dapat mengembangkan model dan metode pembelajaran yang efektif serta menyediakan ruang yang 'bebas' dan leluasa bagi peserta didik untuk belajar dengan karakteristik dan prakarsa mereka.

\section{PEMBAHASAN}

\section{Konsep Dasar Perencanaan Pembelajaran}

Perencanaan adalah proses penetapan dan pemanfaatan sumber daya secara terpadu yang diharapkan dapat menunjang kegiatan-kegiatan dan upaya-upaya yang dilaksanakan secara efisien dan efektif dalam mencapai tujuan. Dalam hal ini, Gaffar dalam Syaiful Sagala menegaskan bahwa perencanaan dapat diartikan sebagai proses penyusunan berbagai keputusan yang akan dilaksanakan pada masa yang akan datang untuk mencapai tujuan yang ditentukan. ${ }^{8}$

Ada beberapa definisi tentang perencanaan yang rumusannya berbeda-beda satu dengan yang lain. Cunningham misalnya, mengemukakan bahwa perencanaan ialah menyeleksi dan menghubungkan pengetahuan, fakta, imajinasi dan asumsi untuk masa yang akan datang dengan tujuan memvisualisasi dan memformulasi hasil yang diinginkan, urutan kegiatan yang diperlukan dan perilaku dalam batasbatas yang dapat diterima yang akan digunakan dalam penyelesaian. Perencanaan di 
sini menekankan pada usaha menyeleksi dan menghubungkan sesuatu dengan kepentingan masa yang akan datang serta usaha untuk mencapainya. ${ }^{9}$

Definisi lain menyebutkan bahwa perencanaan adalah suatu cara untuk mengantisipasi dan menyeimbangkan perubahan. Dari rumusan definisi tersebut dapat disimpulkan bahwa perencanaan merupakan suatu cara yang memuaskan untuk membuat kegiatan dapat berjalan dengan baik, disertai dengan berbagai langkah yang antisipatif guna memperkecil kesenjangan yang terjadi sehingga kegiatan tersebut mencapai tujuan yang telah ditetapkan.

Sedangkan Banghart dan Trull mengemukakan, perencanaan adalah awal dari semua proses yang rasional dan mengandung sifat optimisme yang didasarkan atas kepercayaan bahwa akan dapat mengatasi berbagai macam permasalahan. Dalam konteks pembelajaran, perencanaan dapat diartikan sebagai proses penyusunan materi pelajaran, penggunaan media pembelajaran, penggunaan pendekatan atau metode pembelajaran, dalam suatu alokasi waktu yang akan dilaksanakan pada masa satu semester yang akan datang, dalam rangka mencapai tujuan yang ditentukan.10

Pembelajaran adalah suatu usaha manusia yang penting dan bersifat kompleks. Dikatakan kompleks karena banyaknya nilai-nilai dan faktor-faktor manusia yang turut terlibat di dalamnya. Dikatakan sangat penting, sebab pembelajaran adalah usaha membentuk manusia yang baik. Kegagalan pembelajaran dapat merusak satu generasi masyarakat. Ada yang memahami bahwa pembelajaran tidak dapat disamakan dengan pendidikan. Pembelajaran lebih sering dipahami dalam pengertian suatu kegiatan yang menyangkut pembinaan anak mengenai segi kognitif dan psikomotor semata-mata, yaitu supaya anak lebih banyak pengetahuannya, lebih cakap berpikir kritis, sistematis, dan obyektif, serta terampil dalam mengerjakan sesuatu, misalnya terampil menulis, berenang, memperbaiki alat elektronik dan sebagainya.

Menurut Degeng, pembelajaran atau pembelajaran adalah upaya untuk membelajarkan peserta didik.11 Dalam pengertian ini secara implisit dalam pembelajaran terdapat kegiatan memilih, menetapkan, mengembangkan metode untuk mencapai hasil yang diinginkan. Pemilihan, penetapan, dan pengembangan metode ini didasarkan pada kondisi pembelajaran yang ada. Kegiatan ini pada dasarnya merupakan inti dari perencanaan pembelajaran. ${ }^{12}$

Pandangan tentang istilah pembelajaran terus-menerus berkembang dan mengalami kemajuan. Ada beberapa pemahaman tentang pembelajaran di antaranya yaitu: 1) pembelajaran identik dengan kegiatan mengajar, 2) pembelajaran adalah interaksi belajar dan mengajar, 3) pembelajaran sebagai suatu sistem, dan 4) pembelajaran identik dengan pendidikan. Dalam terminologinya sebagai suatu sistem, pembelajaran mencakup banyak aspek, dan salah satu di antaranya yang cukup urgen adalah perencanaan pembelajaran. ${ }^{13}$

Perencanaan pembelajaran merupakan satu tahapan dalam proses pembelajaran yang sangat bergantung kepada kompetensi keguruan seorang guru. Guru yang baik berusaha sedapat mungkin agar pembelajarannya berhasil. Salah satu faktor yang bisa membawa keberhasilan itu ialah bahwa sebelum masuk ke dalam kelas, guru senantiasa membuat perencanaan pembelajaran sebelumnya. 
Perlu disadari, pembelajaran di sekolah semakin berkembang. Di mulai dari pembelajaran tradisional, yang memiliki ciri-ciri tradisional konservatif berkembang menuju ke sistem pembelajaran modern, yang memiliki ciri-ciri yang sesuai dengan kemajuan zaman. Dalam tahap-tahap perkembangan itu, terdapat perubahan-perubahan dalam sistem pembelajaran dengan semua aspek dan unsur-unsurnya. Jadi, perkembangan pembelajaran itu sejalan dengan perkembangan sekolah.

Thomas E. Curtis dan Wilma W. Bidwell menjelaskan, dalam proses pembelajaran di sekolah (kelas) peranan guru lebih spesifik sifatnya dalam pengertian yang sempit, yakni dalam hubungan proses belajar mengajar. Peranan guru adalah sebagai pengorganisasi lingkungan belajar dan sekaligus sebagai fasilitator belajar. Peranan pertama meliputi peranan-peranan yang lebih spesifik, yakni:

1. Guru sebagai model,

2. Guru sebagai perencana,

3. Guru sebagai inovator,

4. Guru sebagai pemimpin

5. Guru sebagai penunjuk jalan atau pembimbing kearah pusat-pusat belajar. ${ }^{14}$

Dalam kaitan peranannya sebagai perencana, guru berkewajiban mengembangkan tujuan-tujuan pendidikan menjadi rencana-rencana yang operasional. Tujuantujuan umum perlu diterjemahkan menjadi tujuan-tujuan spesifik dan operasional. Dalam perencanaan itu peserta didik perlu dilibatkan sehingga menjamin relevansinya dengan perkembangan, kebutuhan dan tingkat pengalaman mereka. Peranan tersebut menuntut agar perencanaan senantiasa direlevansikan dengan kondisi masyarakat, kebiasaan belajar peserta didik, pengalaman, dan pengetahuan peserta didik, metode belajar yang serasi dan materi pelajaran yang sesuai dengan minatnya. ${ }^{15}$

Dalam hal pentingnya perencanaan pembelajaran, Hamzah B. Uno ${ }^{16}$ menegaskan bahwa hal itu perlu dilakukan agar tujuan untuk melakukan perbaikan pembelajaran dapat tercapai. Upaya perbaikan pembelajaran ini dilakukan dengan asumsi berikut:

1. Untuk memperbaiki kualitas pembelajaran perlu diawali dengan perencanaan pembelajarn yang diwujudkan dengan adanya desain pembelajaran;

2. Untuk merancang suatu pembelajaran perlu menggunakan sistem;

3. Perencanaan desain pembelajaran diacukan pada bagaimana seseorang belajar;

4. Untuk merencanakan suatu desain pembelajaran diacukan pada peserta didik secara perorangan;

5. Pembelajaran yang dilakukan akan bermuara pada tercapainya tujuan pembelajaran, dalam hal ini akan ada tujuan langsung pembelajaran, dan tujuan pengiringnya dari pembelajaran;

6. Sasaran akhir dari perencanaan desain pembelajaran adalah mudahnya peserta didik untuk belajar;

7. Perencanaan pembelajaran harus melibatkan semua variabel pembelajaran;

8. Inti dari desain pembelajaran yang dibuat adalah penetapan metode pembelajaran yang optimal untuk mencapai tujuan yang telah ditetapkan. 
Dari deskripsi di atas disimpulkan bahwa perencanaan pembelajaran merupakan bagian yang sangat penting dalam proses pembelajaran, dan tentunya sangat menentukan tercapainya tujuan pembelajaran itu sendiri. Perlunya menyiapkan rencana pembelajaran atau lesson plan sebenarnya sudah disadari oleh para guru, namun persoalannya adalah tingkat kepedulian para guru untuk menyajikan pembelajaran yang baik dan sistematis, serta tingkat keahlian mereka pada disiplin keilmuan masing-masing yang belum memadai untuk dapat merancang suatu konsep pembelajaran.

\section{Konsep Proses Pembelajaran}

Kegiatan belajar yang berlangsung di sekolah bersifat formal, disengaja, direncanakan, dengan bimbingan guru dan bantuan pendidik lainnya. Apa yang hendak dicapai dan dikuasai oleh peserta didik dituangkan dalam tujuan belajar, dipersiapkan bahan apa yang harus dipelajari, dipersiapkan juga metode pembelajaran, yaitu sesuai dengan cara peserta didik mempelajarinya, dan pada akhirnya dilakukan evaluasi untuk mengetahui kemajuan belajar peserta didik. Penjelasan ini memberi gambaran bahwa kegiatan belajar yang dilaksanakan secara sengaja dipersiapkan dalam bentuk perencanaan pembelajaran. Persiapan pembelajaran ini sebagai kegiatan integral dan proses pembelajaran di sekolah. ${ }^{17}$

Penyusunan program pembelajaran dapat dibedakan menjadi program tahunan, program semester, program mingguan dan program harian. Program tahunan merupakan rencana pembelajaran yang disusun untuk setiap mata pelajaran yang berlangsung selama satu tahun ajaran pada setiap mata pelajaran dan kelas tertentu yang disusun menjadi bahan ajar. Untuk mencapai target dan tujuan yang ditetapkan, maka secara teknis dan operasional dijabarkan dalam program mingguan dan juga harian. ${ }^{18}$ Pada dasarnya rencana pembelajaran adalah manifestasi dari pikiran-pikiran dan konsep-konsep dasar yang tertuang pada kurikulum dan GBPP.

Pembelajaran berkenaan dengan kegiatan bagaimana guru mengajar serta bagaimana peserta didik belajar. Kegiatan pembelajaran ini merupakan suatu kegiatan yang disadari dan direncanakan. Suatu kegiatan yang direncanakan atau kegiatan berencana menyangkut tiga hal, yaitu perencanaan, pelaksanaan dan evaluasi. Demikian juga halnya dengan pembelajaran.

Perencanaan pembelajaran (Instructional Design) dapat dilihat dari berbagai sudut pandang, yaitu:

1. Perencanaan pembelajaran sebagai suatu proses adalah pengembangan pembelajaran secara sistematik yang menggunakan secara khusus teori-teori pembelajaran untuk menjamin kualitas pembelajaran. Dalam perencanaan ini kebutuhan dianalisis dari proses belajar dengan alur yang sistematik untuk mencapai tujuan pembelajaran. Termasuk di dalamnya melakukan evaluasi terhadap materi pelajaran dan aktivitas-aktivitas pembelajaran.

2. Perencanaan pembelajaran sebagai suatu disiplin adalah cabang dari pengetahuan yang senantiasa memperhatikan hasil-hasil penelitian dan teori-teori tentang strategi pembelajaran dan implementasinya terhadap strategi-strategi tersebut. 
3. Perencanaan pembelajaran sebagai sains (science) adalah mengkreasi secara rinci spesifikasi dan pengembangan, implementasi, evaluasi dan pemeliharaan akan situasi maupun fasilitas pembelajaran terhadap unit-unit yang luas maupun yang lebih sempit dari materi pelajaran dengan segala kompleksitasnya.

4. Perencanaan pembelajaran sebagai realitas adalah ide pembelajaran yang dikembangkan dengan memberikan hubungan pembelajaran dari waktu ke waktu dalam suatu proses yang dikerjakan, di mana perencana (guru) mengecek secara cermat bahwa semua kegiatan telah sesuai dengan tuntutan sains dan dilaksanakan secara sistematik.

5. Perencanaan pembelajaran sebagai suatu sistem adalah sebuah susunan dari sumber-sumber dan prosedur-prosedur untuk menggerakkan pembelajaran. Pengembangan sistem pembelajaran melalui proses yang sistematik selanjutnya diimplementasikan dengan mengacu pada sistem perencanaan tersebut.

6. Perencanaan pembelajaran sebagai teknologi adalah suatu perencanaan yang mendorong penggunaan teknik-teknik yang dapat mengembangkan tingkah laku kognitif dan teori-teori konstruktif untuk menemukan solusi terhadap problemproblem pembelajaran. ${ }^{19}$

Mengacu pada berbagai sudut pandang tersebut, maka perencanaan program pembelajaran harus sesuai dengan konsep pendidikan dan pembelajaran yang dianut dalam kurikulum. Penyusunan perencanaan program pembelajaran sebagai suatu proses, disiplin, ilmu pengetahuan, realitas, sistem dan teknologi pembelajaran bertujuan agar pelaksanaan pembelajaran berjalan lebih lancar dan hasilnya lebih baik. Kurikulum khususnya GBPP menjadi acuan utama dalam penyusunan perencanaan pembelajaran, namun kondisi sekolah dan lingkungan sekitar serta kondisi peserta didik dan guru merupakan hal-hal penting yang harus diperhatikan. ${ }^{20}$

Perencanaan pembelajaran dewasa ini terkait erat dengan teknologi pendidikan yang menekankan pembelajaran sebagai suatu sistem. Dapat dijelaskan bahwa pembelajaran sebagai sistem merupakan suatu pendekatan mengajar yang menekankan hubungan sistemik antara berbagai komponen dalam pembelajaran. Hubungan sistemik mempunyai arti bahwa komponen yang terpadu dalam suatu pembelajaran sesuai dengan fungsinya saling berhubungan satu sama lain dan membentuk satu kesatuan. Hubungan sistemik atau penekanan kepada sistem merupakan ciri pertama dari pembelajaran ini. Ciri kedua adalah penekanan kepada perilaku yang dapat diukur atau diamati. ${ }^{21}$

Pembelajaran mempunyai beberapa komponen, yaitu komponen; Tujuan, bahan ajar, metode belajar-mengajar, media dan evaluasi pembelajaran. Pembelajaran yang bercirikan sistem menekankan keterpaduan antara keseluruhan komponen, komponen yang satu berhubungan erat dengan komponen lainnya. Dalam pembelajaran sebagai sistem, tujuan memegang peranan-peranan utama. Tujuan pembelajaran menjadi acuan bagi keempat komponen pembelajaran lainnya. Sebagai suatu acuan, maka dalam penyusunan program pembelajaran, tujuan menjadi komponen pertama yang perlu dirumuskan. Selanjutnya, pemilihan dan perumusan komponen lainnya mengacu pada tujuan. ${ }^{22}$ 
Ciri kedua dari pembelajaran sebagai sistem adalah penekanan kepada perilaku yang dapat diukur dan diamati. Dalam pembelajaran sebagai sistem, tujuan-tujuan yang bersifat umum (tujuan institusional atau tujuan kurikuler) dijabarkan dan dirinci menjadi tujuan-tujuan yang lebih khusus (tujuan instruksional umum dan khusus). Dalam konsep Kurikulum Berbasis Kompetensi (KBK), tujuan pembelajaran di format dalam dua macam pencapaian, yaitu standar kompetnsi dan kompetensi dasar, yang pada substansinya tidak berbeda dan TIU dan TIK di atas.

Pencapaian tujuan-tujuan instruksional khusus ini menjadi sasaran belajar. Proses belajar-mengajar akan mudah ditentukan serta pencapaian tujuan pembelajaran akan mudah diketahui apabila tujuan-tujuan pembelajaran dirumuskan serta bersifat operasional. Tujuan pembelajaran yang bersifat operasional dirumuskan dalam bentuk rumusan perilaku yang dapat diamati atau diukur. Rumusan perilaku yang tidak operasional (tidak dapat diamati atau diukur) sangat sukar pencapaiannya. ${ }^{23}$

Dalam pandangan Oemar Hamalik, model perencanaan pembelajaran terdiri atas komponen-komponen sebagai berikut:

1. Tujuan instruksional; Tujuan-tujuan tertentu yang hendak dicapai dalam jangka waktu pertemuan kelas yang ditetapkan secara tepat dan operasional.

2. Material; Bahan-bahan instruksional yang akan digunakan selama pelajaran dijelaskan dalam kaitannya dengan maksud dan cara yang diintegrasikan ke dalam pelajaran.

3. Motivasi; Deskripsi tentang cara guru merangsang hasrat dan minat peserta didik pada kegiatan permulaan dan selama berlangsungnya pelajaran tersebut.

4. Prosedur; Langkah-langkah dalam urutan instruksional yang disediakan, yang meliputi peranan guru dan peranan peserta didik. Komponen ini memuat tingkah laku guru dan tingkah laku peserta didik selama berlangsungnya pembelajaran.

5. Perkiraan waktu; Pencatatan yang seksama tentang jumlah waktu yang dijadwalkan bagi setiap tahap urutan belajar yang harus disediakan dalam rencana.

6. Penilaian; Kerangka pertanyaan-pertanyaan dan topik-topik untuk menilai kebaikan dan kelemahan pelajaran. Kesempatan bagi peserta didik untuk menilai pelajaran dapat juga disediakan.

7. Kerja mandiri dan tingkat lanjut; Penugasan sebagai tindak lanjut dijelaskan dalam rencana. Misalnya kegiatan-kegiatan melakukan kunjungan ke pusat-pusat belajar dan perpustakaan, tugas pekerjaan rumah berdasarkan tujuan-tujuan pelajaran dan sebagainya. ${ }^{24}$

Dalam proses pembelajaran, guru, yang sekaligus pendidik, memegang posisi dan peranan utama. Guru harus mengantar peserta didik untuk berpartisipasi aktif dalam kegiatan pembelajaran dan mengembangkan segenap potensi paedagogisnya dalam mencapai tujuan pembelajaran. Abdullah Idi menjelaskan peranan guru dalam melaksanakan proses pembelajaran sebagai berikut:

1. Merencanakan unit pembelajaran.

2. Mendiagnosis kesulitan belajar peserta didik. 
3. Menguraikan kegiatan belajar yang sesuai.

4. Menghubungkan pengalaman belajar dengan minat peserta didik secara individual.

5. Mengorganisasikan kurikulum.

6. Mengevaluasi kemajuan peserta didik. 25

Dalam perencanaan kegiatan pembelajaran, pendidik perlu menentukan tujuan yang jelas mengenai apa yang hendak dicapai dan mempertimbangkan alasan mengajarkan hal itu, yakni alasan menyampaikan suatu pokok bahasan, sehingga arah pekerjaan pendidik terarah dan efektif. Karenanya, pelajaran yang disajikan harus mempunyai perencanaan, pengoreksian, atau kesesuaiannya dengan rencana pelajaran. Jelasnya, tujuan seorang pendidik dalam membuat rencana pelajaran adalah agar tercipta kondisi aktual sehingga dapat mendukung pencapaian tujuan pembelajaran yang ditetapkan secara optimal, baik tujuan khusus maupun tujuan umum. ${ }^{26}$

Selanjutnya, menurut Abdullah Idi, dalam merencanakan pembelajaran suatu satuan bahasan tertentu bagi peserta didik, pendidik harus memahami tujuan yang ingin dicapai, materi atau bahan yang diperlukan, metode atau alat yang digunakan dan prosedur penilaiannya. Apabila seorang pendidik atau guru hendak mengajarkan suatu bahasan tertentu, maka perlu memahami tahap-tahap berikut:

1. Merumuskan tujuan-tujuan instruksional khusus (Kompetensi Dasar) yang ingin dicapai.

2. Menyusun alat evaluasi.

3. Merencanakan program kegiatan mengajar.

4. Melaksanakan program. ${ }^{27}$

Yang patut disayangkan, ada sebagian guru yang beranggapan bahwa mengajar di kelas tidak perlu repot-repot menyiapkan bahan. Cukup dengan mengetahui subbahasan yang akan diajarkan dan berbekal kemampuan orasi, pembelajaran sudah terlaksana. Ada pula yang bergantung sepenuhnya kepada lembar kerja siswa (LKS) yang cukup banyak digunakan dalam pelaksanaan Kurikulum Tingkat Satuan Pelajaran (KTSP) sekarang ini. Guru cukup membagikan LKS dan menyuruh setiap peserta didik mengerjakan soal-soal lalu dikumpulkan, tanpa dikoreksi dan penjelasan setiap item soal. Fenomena ini merupakan gambaran nyata ketidakmampuan, atau mungkin ketidakpedulian, para guru untuk melaksanakan pembelajaran dengan didasari perencanaan yang matang dan tepat.

Dalam penyusunan perencanaan program pembelajaran seorang pendidik atau guru harus menekankan terselenggaranya proses pembelajaran secara lebih lancar dan hasilnya lebih efektif. Olehnya itu, ada beberapa hal yang perlu diperhatikan dalam perencanaan program pembelajaran, yaitu:

1. Kurikulum; Dalam perencanaan pembelajaran atau penyusunan suatu program pembelajaran, hal pertama yang perlu mendapat perhatian adalah kurikulum, terutama GBPP-nya. Dalam GBPP biasanya telah tercantum tujuan kurikuler, tujuan instruksional, pokok bahasan serta jam pelajaran untuk mengajarkan pokok bahasan tersebut. 
2. Kondisi sekolah; Perencanaan pembelajaran juga perlu memperhatikan keadaan sekolah, terutama tersedianya sarana-prasarana dan alat bantu pelajaran. Saranasarana dan alat bantu pelajaran ini menjadi pendukung terlaksananya berbagai aktivitas belajar peserta didik.

3. Kemampuan dan perkembangan peserta didik; Dalam menyusun atau merencanakan program pembelajaran komponen peserta didik juga perlu mendapat perhatian. Agar bahan dan cara belajar ini sesuai dengan kondisi peserta didik, maka penyusunan skenario/program pembelajaran perlu disesuaikan dengan kemampuan dan perkembangan peserta didik. Dalam hal ini keluasan dan kedalaman bahan ajaran perlu disesuaikan dengan kemampuan dan perkembangan peserta didik.

4. Keadaan guru; Keadaan dan kemampuan guru sesungguhnya tidak perlu menjadi hal yang perlu diperhatikan, sebab guru dituntut memiliki kemampuan dalam segala hal yang berkenaan dengan pelaksanaan pendidikan dan pembelajaran. Jika suatu saat ia merasa memiliki kekurangan, itu merupakan tuntutan baginya untuk belajar dan meningkatkan kompetensi dirinya dalam kapasitasnya sebagai pengajar dan pendidik.

Dalam pandangan penulis, program sertifikasi tenaga-tenaga pendidik, guru dan dosen, yang dilaksanakan pemerintah yang berimplikasi pada peningkatan kesejahteraan mereka tentunya harus diimbangi dengan keseriusan serta kesungguhan dalam melaksanakan tugas. Tunjangan profesional yang diberikan kepada para pendidik yang telah tersertifikasi pada dasarnya berasal dan uang rakyat. Nilai material tersebut mengandung makna adanya harapan besar dari rakyat dan tanggung jawab para tenaga pendidik untuk mencerdaskan anak-anak mereka. Keberhasilan pendidikan tentunya juga ditentukan oleh proses pembelajaran yang mengacu pada kurikulum yang baik dan perencanaan pembelajaran yang efektif serta efisien.

\section{SIMPULAN}

Perencanaan pembelajaran merupakan hal yang sangat penting dalam mensukseskan proses pembelajaran pada level dan bentuk pendidikan mana pun. Berdasar dari hal tersebut dapat disimpulkan hal-hal sebagai berikut:

1. Pembelajaran merupakan bagian dari pendidikan, mengacu pada konsep yang lebih luas dan lintas kultural masyarakat Indonesia yang demikian majemuknya, maka pendidikan diselenggarakan berdasarkan rencana yang matang, mantap, jelas dan lengkap, menyeluruh, rasional, dan objektif untuk menjadikan peserta didik sebagai warga negara yang baik. Keberhasilan pendidikan banyak ditentukan bagaimana optimalisasi upaya pendidik dalam merencanakan dan melaksanakan serta mengevaluasi sistem pembelajarannya.

2. Dalam konteks pembelajaran, perencanaan dapat diartikan sebagai proses penyusunan materi pelajaran, penggunaan media pembelajaran, penggunaan pendekatan atau metode pembelajaran, dalam suatu alokasi waktu yang akan dilaksanakan pada masa satu semester yang akan datang, dalam rangka mencapai tujuan yang 
ditentukan. Ringkasnya, perencanaan pembelajaran merupakan skenario pembelajaran yang menjadi acuan dan pola pelaksanaan program pembelajaran bagi pihak pendidik, dan pengalaman belajar yang sistematis dan efektif bagi pihak peserta didik.

3. Perencanaan program pembelajaran harus sesuai dengan konsep pendidikan dan pembelajaran yang dianut dalam kurikulum. Penyusunan perencanaan program pembelajaran sebagai sebuah proses, disiplin, ilmu pengetahuan, realitas, sistem dan teknologi pembelajaran bertujuan agar pelaksanaan pembelajaran berjalan lebih lancar dan hasilnya lebih baik.

\section{CATATAN AKHIR:}

1. Abuddin Nata, Tokoh-tokoh Pembaruan Pendidikan Islam di Indonesia, Jakarta: PT RajaGrafindo Persada, 2005, h. vi.

2. Syaiful Sagala, Konsep dan Makna Pembelajaran, Bandung: Alfabeta, 2005, h. 4.

3. N.S. Degeng, Pandangan Behavioristik vs Konstruktivisiik: Pemecahan Masalah Belajar. Abad XXI, dalam C. Asri Budianingsih, Belajar dan Pembelajaran, Jakarta: Rineka Cipta, 2005, h. 2.

4. Ibid., h. 5 .

5. Syaiful Sagala, op. cit., h. 63.

6. Ibid.

7. Lihat ibid.

8. Syaiful Sagala, op. cit., h. 141.

9. Hamzah B. Uno, Perencanaan Pembelajaran, cet. III; Jakarta: Bumi Aksara, 2008, h. 1.

10. Ibid.

11. N. S. Degeng, Buku Pegangan Teknologi Pendidikan Pusat Antar Universitas untuk Peningkatan dan Pengembangan Aktivitas Instruksional Universitas Terbuka, Jakarta: Depdikbud. RI, Dirjen Dikti, 1993, h. 1.

12. Hamzah B. Uno, op. cit., h. 2.

13. Oemar Hamalik, Proses Belajar Mengajar, cet. VI; Jakarta: Bumi Aksara, 2007, h. 53-54.

14. Oemar Hamalik, Perencanaan Pembelajaran Berdasarkan Pendekatan Sistem, cet. VII; Jakarta: Bumi Aksara, 2008, h. 45.

15. Ibid., h. 46.

16. Ibid., h. 3.

17. Syaiful Sagala, op. cit., h.135.

18. Ibid.

19. Ibid., h .136-137.

20. Proses pembelajaran pada hakikatnya adalah operasionalisasi dari kurikulum, khususnya garis-garis besar program pembelajaran (GBPP) bidang studi tertentu. Upaya yang bisa dilakukan agar pelaksanaan program pembelajaran sesuai dengan rambu-rambu yang ada dalam GBPP adalah: 1) menelaah dan memahami dengan baik GBPP, 2) menyusun satuan pelajaran untuk satu catur wulan atau semester, 3) menyediakan sumber (alat) fasilitas belajar, dan 4) melakukan penilaian hasil belajar. Ringkasnya, GBPP tidak lain merupakan implementasi dan sebuah perencanaan program pembelajaran yang pada intinya menyiapkan dan melaksanakan kegiatan pembelajaran yang tepat, efektif dan efisien. Lihat Nana Sujana, Pembinaan dan Pengembangan Kurikulum di Sekolah, cet. V; Bandung: Sinar Baru Algesindo, 2005, h. 107-110.

21. R. Ibrahim \& Nana Syaodih S., Perencanaan Pembelajaran, cet. II; Jakarta: Rineka Cipta, 2003, 
h. 51.

22. Ibid., h. 52.

23. Ibid.

24. Oemar Hamalik, Pendekatan Baru Strategi Belajar Mengajar Berdasarkan CBSA, Bandung: Sinar Baru Algensindo, 2003, h. 7-8.

25. Abdullah Idi, Pengembangan Kurikulum Teori dan Praktek, cet. II; Yogyakarta: Ar-Ruz Media, 2007, h. 235.

26. Ibid.

27. Ibid., h. 242-24.

\section{DAFTAR PUSTAKA}

Budianingsih, C. Asri. Belajar dan Pembelajaran. Jakarta: Rineka Cipta, 2005.

Degeng, N.S. Buku Pegangan Teknologi Pendidikan Pusat Antar Universitas untuk Peningkatan dan Pengembangan Aktivitas Instruksional Universitas Terbuka. Jakarta: Depdikbud. RI, Dirjen Dikti, 1993.

Hamalik, Oemar. Proses Belajar Mengajar. Cet. VI; Jakarta: Bumi Aksara, 2007.

Perencanaan Pembelajaran Berdasarkan Pendekatan Sistem. Cet. VII; Jakarta: Bumi Aksara, 2008.

Pendekatan Baru Strategi Belajar Mengajar Berdasarkan CBSA. Bandung: Sinar Baru Algensindo, 2003.

Ibrahim, R. \& Nana Syaodih S. Perencanaan Pembelajaran. Cet. II; Jakarta: Rineka Cipta, 2003.

Idi, Abdullah. Pengembangan Kurikulum Teori dan Praktek. Cet. II; Yogyakarta: Ar-Ruzz Media, 2007.

Nata, Abuddin. Tokoh-tokoh Pembaruan Pendidikan Islam di Indonesia. Jakarta: PT RajaGrafindo Persada, 2005,

Sagala, Syaiful. Konsep dan Makna Pembelajaran. Cet. II; Bandung: Alfabeta, 2005.

Sujana, Nana. Pembinaan dan Pengembangan Kurikulum di Sekolah. Cet. V; Bandung: Sinar Baru Algesindo, 2005

Uno, Hamzah B. Perencanaan Pembelajaran. Cet. III; Jakarta: Bumi Aksara, 2008. 